\title{
Total and Authoritary State Regimes
}

\section{Vladimir Valentinovich Kozhevnikov}

Department of Theory and History of State and Law, Omsk State University Dostoevsky, Omsk, Russia

Email: kta6973@rambler.ru

\section{Abstract:}

This scientific article analyzes and dialectically evaluates non-democratic state regimes, which, from the position of the author, cannot be definedas anti-democratic regimes. This assessment of the undemocratic state regime is transferred to its two main varieties - authoritarian and totalitarian regimes, focusing on the negative and positive aspects of both. Special attention is paid to the problem of correlation between totalitarian and authoritarian state regimes.

Keywords:

non-democratic state regimes; restriction of the rights and freedoms of citizens; arbitrariness; concentration of state power; totalitarian state regime; authoritarian state regime; correlation between totalitarian and authoritarian state regimes

\section{Introduction}

The relevance of this scientific article is determined by the fact that among other elements of the form of the state - the form of government, the form of state structure, it is the state regime that is of paramount importance. It seems that attention should be paid to the fact that here we operate with the concept ofstate and not political, meaning that the latter characterizes the political system of society.

\section{Research Methods}

When preparing a scientific article, the following methods were used:

1. General philosophical (dialectical-materialistic), which is used in all social sciences;

2. General scientific (analysis and synthesis, logical and historical, comparisons, abstractions, etc.), which are used not only by the theory of state and law, but also by other social sciences;

3. Special methods (philological, cybernetic, psychological, etc.), developed by special sciences and widely used for the knowledge of state and legal phenomena;

4. Private scientific (formal legal, interpretation of law, etc.), which are developed by the theory of state and law.

\section{Discussion}

\subsection{General Characteristics of Non-Democratic State Regimes}

Speaking about non-democratic regimes, Mikhail Nikolaevich Marchenko notes that the latter is characterized by the elimination or significant restriction of the rights and freedoms of citizens, the prohibition of opposition parties and other organizations, the restriction of the role of elected state bodies and the strengthening of the role of executive bodies, the concentration of huge powers in the hands of the head of state or government., reducing the parliament and other government bodies to the position of purely formal institutions [1]. According to 
Magomed Imranovich Abdulaev and Sergei Aleksandrovich Komarov, "an anti-democratic (autarkic) political-state regime is a set of methods for exercising state power on the basis of arbitrariness, without taking into account the opinions of both the majority and the minority" [2]. Vitaly Vasilievich Oksamytny generally recognized states with an anti-democratic regime as anomalous, which "... are in a state of anomie (from the French anomie - the absence of a norm, law), that is, in a crisis of society and its value system" [3]. Yuri Albertovich Dmitriev, specifying, emphasizes that non- democratic regimes are based on the concentration of all state power in the hands of one person (dictator) or a group of persons (junta).

The scientist believes that "such regimes are usually called autocratic (gr. Autokrates autocratic) or authoritarian (Latin auctoritas - establishing a regime of personal power) [4]. Rosalina Vasilievna Shagieva, noting that the undemocratic regime was historically presented in the form of despotism, tyranny, etc., argues that "undemocratic political and legal regimes have been and remain in states where power is concentrated in the hands of a narrow social group, its bodies are formed by appointment or by purely formal elections, the distribution of power functions between them is conditional, the power relies mainly on the power structures, the individual is suppressed, his rights, freedoms and natural interests are infringed, the media, trade unions and many social and political formations are state has primacy over the law, its organs are connected not only with legal norms, but with instructions from above "[5]. From the position of Magomed Imramovich Abdulaev, the anti-democratic regime is characterized by the elimination of political rights and freedoms, the removal of the people from state power, its usurpation by individuals or a group of persons, the suppression of any dissent, the abolition of representative bodies of power or their transformation into obedient instruments of expressing the will of actual leaders [6] ... In the legal literature, irrespective of the types of anti-democratic regimes, their following characteristic features are cited: state control over all spheres of public life; control over public organizations (trade union, youth, sports, etc.); personality is largely devoid of subjective rights, although formally they can be proclaimed even in constitutions; the primacy of power decisions over law and violation of the rule of law; militarization of public life; ignoring the interests of state entities, especially national minorities [7].

It seems that one should agree with the opinion that "the general drawback of nondemocratic political systems is that they are not under the control of the people, which means that the nature of relations with citizens depends, first of all, on the will of the rulers" [8]. In legal science, undemocratic regimes are often called anti-democratic [9]. At the same time, totalitarian and authoritarian regimes are perceived as negative phenomena, opposed to "good" democracy. However, at the same time, at least the following circumstances should be taken into account. First, democracy itself is flawed. At one time, Alexander Nikolayevich Yakovlev wrote that "like everything else, democracy is not an absolute Good. In the hands of a person, it can be directed to both Good and Evil. And so that the latter does not happen, one must be well aware of all the shortcomings dictated by the nature of this beloved phenomenon" [10]. Secondly, a totalitarian and authoritarian state regime cannot be treated absolutely negatively. In this regard, Yuri Anatolyevich Kudryavtsev notes that the political regime is formed as a result of many constituent factors and is determined by the socio-economic and cultural foundations of society. That is why, the author concludes, one cannot say that a totalitarian regime is always bad, and a democratic one is good for any society. Considering that any political regime is the result of certain preconditions, the existence of which is conditioned by objectively established social relations of the widest profile; society gives preference to one or another type of regime, based on the priority of the tasks set by it, [11] the scientist comes to the conclusion that the political regime should be considered from the point of view of legal, social expediency in relation to a 
particular country, which explains the validity of replacing the term " anti-democratic political regimes \&quot;to\&quot; non-democratic political regimes [10].

\subsection{Authoritarian State Regime: Negative and Positive Aspects}

The authoritarian state regime of all types of regimes, both undemocratic and undemocratic, is perhaps the least studied today, although, from the standpoint of scientists, "states with authoritarian political regimes are currently the most widespread type of states in the context of their classification by political regimes. \&Quot; At the same time, it is noted that "despite the fact that the absolute majority of modern states define themselves as democratic, the actual content of state policy, the methodology of exercising political power does not allow us to recognize the validity of this statement. Such states can be considered, rather, not as democratic, but as one of the varieties of an authoritarian political regime" [12]. Authoritarian regimes seek their theoretical basis in various versions of the concept of heroes and crowds. One such option is elite theories, especially the theory of the ruling elite, which rejects the concept of pluralistic democracy as overly idealistic. The concepts of the elitists found continuation in the theories of mass society and mass state. Their supporters represent society in the form of a crowd (a set of crowds), in which an individual person obeys the behavior of the crowd and acts in accordance with primitive emotions - patriotism, racism, hatred, etc. although she does not realize it.

The leader uses the crowd to implement his ideas, constantly maintaining a charismatic tension in the masses. In many developing countries, the concepts of authoritarians (and sometimes supporters of totalitarianism) have found their expression in the theories of guided (orchestral) democracy, which proceed from the premise that the need for accelerated economic development of a country and overcoming conflicts in multi-ethnic societies requires strict management. For this purpose, a single ideology is created from above, a "progressive party" headed by a charismatic person (leader) who uses state power and other mechanisms (including ideological ones) to achieve the set goals. The main role in directed democracy is played by the state, state power (including, often, the power of the army) [13]. As political scientists note, the basis for the transformation of leadership into leaderism is in the archaic simplicity of patriarchal relations. The complex mechanism of modern power is being replaced by orders, the wishes of the leader, and the obedience of followers. Society is identified with the state, politics with ideology, the will of the leader with the will of the people.

The perception of reality becomes irrational, because the relationship between the leader and his entourage is losing a rational basis. The leader resorts to the most accessible manipulations of public consciousness, which perceives everything new as alien and alien, hostile. The desire of the entourage to endow the leader with extraordinary abilities, extraordinary wisdom and perspicacity, knowledge of what his relatives and subordinates and, naturally, the country and people should know, becomes irrational [14]. Elena Anatolyevna Lukyanova and Ilya Georgievich Shablinsky believe that the state ideology in such cases is viewed as an additional tool that strengthens the status quo. In this regard, two approaches to the formation of the ideological position of the authorities differ: 1) the ideological attitudes of the head of the regime (ruling group) are widely promoted precisely as the attitudes of the ruling and dominant political force in the state, but does not become the ideology of the state; 2) the consolidation of such attitudes in official acts of the state-laws or even in constitutions that are binding on citizens. When this starts to happen, it is generally accepted that the political regime degenerates from authoritarian to totalitarian [15].

In the legal literature, the authoritarian regime is revealed through its concepts and the system of corresponding features. So, Leonid Pavlovich Rasskazov believes that the very name 
of this regime conceals its essence restriction of democracy, the use of violent methods of ruling [16]. Lev Ivanovich Spiridonov defined the authoritarian regime as intermediate between totalitarian and democratic regimes, transitional from one to another, which causes blur indistinctness of its properties. According to the author, its main feature is that state power does not have a totalitarian character and does not achieve complete control over all spheres of economic, political and cultural life. it does not have a single state ideology obligatory for all, which is replaced by constructions such as the theory of national interest, ideas of patriotism, and so on.

Management is carried out by not as tough means as under totalitarianism. There is no mass terror [17]. Nikolai Andreevich Pyanov, also recognizing the authoritarian regime as an intermediate between democratic and totalitarian regimes, wrote that the former tends to either grow into a totalitarian regime, or transform into a semi- democratic and then into a democratic one. However, recognizing the authoritarian regime as an independent species, the author calls the system of its important, specific features: 1) being an anti-democratic regime, it is a more liberal regime than a totalitarian one, since it carries some features of a democratic regime; 2) it is characterized by the fact that state power is concentrated in the hands of a dictator or a ruling elite group (junta, party elite, military, bureaucratic or religious elite). The principle of electiveness of state bodies, accountability and control over their population is narrowed or reduced to nothing. Representative bodies of power can exist, but at the same time they do not play a decisive role in the management of society and turn into a decoration that covers up authoritarian power; 3) the principle of separation of powers is ignored while strengthening the executive bodies, which often subordinate all other state bodies to themselves. Courts often act as subsidiary bodies as extrajudicial bodies can also be used; 4) power, command, bureaucratic methods of state administration prevail, at the same time terror and mass repressions are practically not used in the exercise of power; 5), unlike totalitarian regimes, there is no total state control over certain spheres of public life.

The economy, culture, and private life can be relatively independent from state power (although not always). At the same time, under authoritarian regimes there is always a monopoly on political power, there is still partial censorship over the mass media; 6) limited political pluralism is allowed. The constitutions proclaim the freedom of formation of political parties, however, the state power, by special laws, allows the activities of only some of them (those that are guided by the line developed by the ruling party). Opposition is either not allowed or allowed only within certain limits; 7) under an authoritarian regime, unlike a totalitarian regime, there is no single state ideology obligatory for the entire society (a certain pluralism in the field of ideology); 8) democratic rights and freedoms in authoritarian states are mainly proclaimed, but not really ensured. A state of emergency or other special situation is often introduced, which in practice is directed against the of the regime. In this regard, the person is deprived of guarantees of security in relations with the authorities; 9) under authoritarian regimes, the role of the head of state (leader) is very high. At the same time, unlike totalitarian states, a leader in authoritarian regimes is not charismatic [18]. V.E. Chirkin pointed out that under this regime, methods of coercion, or even direct violence, prevail, while certain methods of liberalism are preserved. Representative bodies remain, but elections are a formality, since the activities of a political party have been discontinued. The constitutional rights of citizens are openly violated, and the state authorities see their role not in protecting these rights, but primarily in serving the clan of the president, his entourage or the entourage of the prime minister. There is no real participation of citizens in state affairs, elections are ostentatious and cannot remove old forces from power or bring new parties to power; the principle prevails not of election, but of appointment; the political activity of citizens and public associations is low: it is constrained by the framework of 
legislation and established practice [19]. In another work, he singled out the varieties of authoritarian regimes (oligarchic, constitutional-authoritarian, etc.) [13]. Grigory Vasilievich Golosov focuses on the following types of it: traditional regime, competitive oligarchy, authoritarian-bureaucratic regime (military and populist), egalitarian-authoritarian regime, authoritarian-inegalitarian regime [20]. It should be noted that it is traditionally viewed as a transitional, intermediate regime devoid of specific properties and features, combining features characteristic of both totalitarian and democratic regimes [17, 21]. We believe that the statements of Oksana Gennadievna Kharitonova are fundamental here, who, calling such democratic institutions as political parties, parliament and elections, according to which they are \& quot; the main elements capable of preserving a non-democratic regime in non-violent ways.\&quot; The author believes that "these institutions do not lead to a change of leadership, are not institutions of vertical responsibility, but they are necessary to resolve intra-regime conflicts and prevent potential destabilization of the regime" [22].

Vladimir Yuryevich Lukyanov defines an authoritarian regime as \& quot; a regime of an intermediate, transitional type, located between the totalitarian\&quot; [23]. We believe that this can hardly be considered true, especially since the combination of the signs of totalitarianism and democracy in itself does not yet speak of the transitional nature of such a regime [10]. Roman Anatolyevich Romashov and Mikhail Viktorovich Salnikov, for example, in this regard, rightly note that authoritarian regimes are really political and legal systems that have developed and function in specific states. At the same time, in a number of states, authoritarianism is viewed not as a transitional, but as an established, stable form of political regime (China. South Korea) [24]. Noteworthy is the position of Maxim Gennadievich Tirsky, who believes that it is inadmissible to use the so-called exclusive definition in understanding an authoritarian regime, i.e., the definition of authoritarianism as everything that cannot be directly attributed to extreme types of political regimes (totalitarian and democratic). According to the scientist, "understanding the desire ... to delimit an authoritarian regime from others ... one cannot agree to such an "intermediateness of authoritarianism".

The laws in such a society are built on a permissive type - everything that is not allowed by the leader is prohibited. The norms of political behavior are created by the hierarchy of ideological authorities, among which the highest is the decisions of the leader, whose power is unlimited and uncontrollable [8]. Valery Nikolaevich Protasov and Natalya Valerievna Protasova, assessing the authoritarian regime, believe that state power with such a regime can serve as an effective means of modernizing society and gradually introducing democratic institutions. He has a fairly high ability to ensure public order, rapid reorganization of social structures despite the resistance of the conservative forces. Concentration of great efforts and resources on solving certain issues. Scientists attribute to the weaknesses of the authoritarian regime the complete dependence of state policy on the position of the head of state or a group of top leaders, the absence of effective institutions that protect the population from arbitrariness [21].

Assessing the authoritarian regime, scientists believe that the main meaning of authoritarian rule is usually seen by their supporters in political stabilization, in protecting entrepreneurs and property owners from all kinds of radical movements and organized crime, that is, in ensuring the most favorable conditions for business and the development of national economies. Indeed, many scholars tend to see a strong authoritarian state as the most effective tool for transforming transitionalism. American lawyer David Epter believes that "in conditions of modernization, democratic political institutions are not very appropriate" [26]. Perhaps one of the first Russian jurists who paid attention to this problem was Nikolai Mikhailovich Korkunov, 
who substantiated the need for state intervention in the life of society in cases where "citizens cannot achieve prosperity and harmony by their own efforts" [27].

Vasily Andreevich Fedorov calls authoritarian methods of management \& quot; the guarantor of the modernization and transformation of social relations\&quot; [28]. Noting some of the advantages of an authoritarian regime (a high ability to ensure political stability and public order, to mobilize public resources for solving certain problems, to overcome the resistance of political opponents, the ability to solve progressive problems associated with bringing the country out of the crisis), it is concluded that authoritarianism was the desired regime in a number of countries after the Second World War against the background of acute economic and social contradictions that existed in the world [8]. But, evaluating these goals as declared, the authors believe that the obvious goal of all dictatorial regimes is to obtain unlimited uncontrolled power and the economic benefits associated with it [15].

Tatyana Evgenievna Vorozheikina believes that \&quot; the majority of authoritarian regimes were, to one degree or another, focused on the implementation of socio- economic modernization and therefore can be, albeit with a large degree of convention, called the regimes of authoritarian modernization [29].

\subsection{Totalitarian State Regime: Negative and Positive Aspects}

Another main type of non-democratic state regime is a totalitarian regime, understood as "terrorist, characterized by violence, complete suppression of democratic freedoms and individual rights" [30]. In the philosophical encyclopedic dictionary, totalitarianism (from Lat. Totalis - whole, complete) is understood as a socio-political system, which is characterized by a comprehensive \&quot; command intervention of the authoritarian state in all spheres of life and activities of society and individuals [31]. The concept of totalitarianism was developed by the Italian philosopher, ideologist of Italian fascism Giovanne Gentile at the beginning of the twentieth century, who believed that the primary role of the state in society is the implementation of national destiny. And since the state implements the fate of the nation, it must have unlimited power and be totalitarian. The term "totalitarianism" was introduced into the political lexicon by Benito Mussolini to characterize the fascist regime in Italy. Explaining the concept of the fascist state, Mussolini proclaimed fascism as an absolute state, in comparison with which individuals and groups have relative importance. Anatoly Borisovich Vengerov believed that the totalitarian regime was a product of the twentieth century; these are fascist states, socialist states of the period of the "personality cult". The term itself appeared in the late 1920s, when some political scientists sought to separate the socialist state from democratic states and were looking for a clear definition of the socialist statehood [32]. Yuri Gaikovich Sumbatyan notes that the new ideology of totalitarianism is based on the monopoly of totalitarian culture, which appeals not so much to reason as to emotions, trying to force people to believe in the truth of the dominant ideological doctrine, in the justice of its slogans and dogmas [33]. Igor Nikolaevich Rassokha connects the emergence of totalitarianism primarily with the difficulties of modernization, the transition of society to the industrial stage of development. with the attempts of the ruling elite to overcome these difficulties by means of emergency-nationalization, overbureaucratization, uniform politicization and militarization of the whole society.

Totalitarian ideology seeks to fill the inner, spiritual space of every person as much as possible. This ensures the unification of people, their solidarity, unanimity of assessments and views, the necessary massive support for totalitarian regimes. The next feature of the analyzed ideology is manifested in the priority of collective values over individual ones; the interests of society, the state, and social groups are initially set higher than the interests of the individual. 
Friedrich Hayek, criticizing the totalitarian regime, "only those whose goals coincide with the goals of society can be considered real citizens. It inevitably follows from this that a person can be respected only as a member of a group, that is, only to the extent and to the extent that he contributes to the implementation of generally recognized goals. This, and not the fact that he is a person, determines his human dignity" [38]. The totalitarian state declares that there is only state interest. In this regard, Ivan Aleksandrovich Ilyin wrote that "totalitarianism consists in the exclusion of all and any initiative of citizens: their personal freedom, their corporate organization, their local and professional self-government, their discretion in personal and family matters, their economic initiative and their cultural initiative [39]. It seems that it is necessary to pay attention to such a feature of the ideology of totalitarianism that it has similarities with religion. Elgiz Abdulovich Pozdnyakov notes the following in this regard: "Where religious faith gives weakness, where it begins to lose its influence and positions, secular ideology immediately begins to penetrate the cracks that have formed. It forms the basis of moral values for many millions of people who have lost faith in religious ideals or have never believed in them. At the same time, where religious faith is institutionalized - and this sooner or later happens with any religion - it itself begins to transform itself first into religious, and then into various secular ideologies" [40].

\subsection{On the Relationship between Totalitarian and Authoritarian State Regimes}

It seems that an important question is what place does totalitarianism occupy in comparison with other regimes and, above all, with authoritarian? The point is that totalitarianism is called an authoritarian-dictatorial regime and vice versa: some totalitarian regimes are considered almost as authoritarian. In this respect, I think, we should support Anatoly Pavlovich Butenko, who asserts that authoritarianism and totalitarianism are two significantly different types of non-democratic regimes.

Under totalitarianism, the civil society that began is purposefully etated. It is also noted that under authoritarianism, political power, giving a person a certain opportunity for selfrealization in civil society, hinders the active independent political activity of citizens, as a result of which political absintheism is characteristic of authoritarianism. Under totalitarianism, due to the extreme politicization and ideologization of the entire life of people, they cannot stay away from political life, and the political regime itself is permanently trying to keep people in a state of political tension. Political absentism is not only discouraged, as under authoritarianism, but is also viewed as a great evil [53]. Anatoly Pavlovich Butenko, differentiating authoritarianism and totalitarianism, draws attention to the fact that under authoritarianism. There is an insurmountable distance between the political leader and the people: the usurper and the people. The totalitarian leader and the people are inseparable organic integrity. A totalitarian leader, as a rule, is the favorite of the crowd, of the masses. The cult of the leader is a characteristic feature of totalitarianism [51]. Evaluating totalitarianism, we note that its manifestations can be both positive and negative at the same time, so it is rather difficult to evaluate them from only one side. So, under a totalitarian regime, the state is given the opportunity not to fully experience the influence of foreign states.

The state financed the development of science, providing substantial into its development, which can be assessed as a positive aspect of the totalitarian regime. However, as Mikhail Nikolaevich Marchenko notes, "the influence of a totalitarian state in the process of formation on science meant not only rapid development and an increase in government funding, it also meant less "freedom" [53]. The lack of freedom in scientific research, when scientists could not pursue the scientific direction that was of interest to them, of course, should be considered as a disadvantage of the regime. Generally speaking, when studying the issue of the 
nature of a totalitarian regime, it is very likely that it will be defined as a more negative than a positive phenomenon for the development of the state and society.

Totalitarianism actually to society acceptable options for behavior through the education system, mass media, norms of culture, art, etc. Therefore, over time, the overwhelming majority of citizens are no longer able to independently think about economic and socio-political reality. In addition, under totalitarianism, society is ideologized to the extreme by the state, which is quite understandable, since it becomes easier to exercise state control through the establishment of an ideological structure. Here society is merging with a specially built system of control and monitoring of its members, since among the participants of such a system, in addition to state law enforcement agencies, there may be members of a totalitarian society who monitor and denounce other citizens. It is necessary to take into account the essential role in the life of the state with a totalitarian state regime, which is played by the so-called that is, the closed nature of the activity. including its strictest isolation from any manifestation of foreign capital. Along with other manifestations, this presupposes the non-admission of free contacts with citizens of other states, or a significant limitation of such cooperation.

\section{Conclusion}

In conclusion of this article, the following conclusions can be drawn: 1) non-democratic state regimes, the main of which are authoritarian and totalitarian, should not be defined as antidemocratic, because, firstly, democracy itself is faulty; secondly, one cannot treat them absolutely negatively, because any regime is formed as a result of many constituent factors and is determined by the socio-economic and cultural foundations of society; 2) an authoritarian state regime, characterized by the fact that state power is concentrated in the hands of a dictator (ruling elite), where the principle of separation of powers is ignored when the executive bodies are strengthened, forceful methods of state administration prevail, etc., has both weak (complete dependence of state policy from the position of the head of state or a group of top leaders, the absence of institutions that protect the population from arbitrariness), and strengths (high ability to ensure political stability and public order, mobilize public resources to solve certain problems, the ability to solve progressive problems associated with the withdrawal of the country from crisis); 3) a totalitarian state regime, which is based on a single state ideology, forcibly imposed on the entire society, methods of physical, mental and ideological violence from the party-state machine, can also be assessed as positive (for example, the development of science, free education), so and negatively (for example, the absolute dominance of the executive over the legislative branch, the dictatorship of the former, the rejection of political pluralism). At the same time, it is highly probable that it will be defined as a more negative than a positive phenomenon for the development of the state and society.

\section{References}

[1]. Marchenko Mikhail Nikolaevich. Problems of the general theory of state and law: a textbook in 2 volumes. M.: Prospect, 2007. Vol.1. State. Pp.256-257.

[2]. Abdulaev Magomed Imranovich, Komarov Sergey Alexandrovich. Problems of the theory of state and law: textbook. Saint Petersburg: Peter, 2003, P. 80.

[3]. Oksamytny Vitaly Vasilevich. Theory of state and law: textbook. Moscow: IMPE-PABLISH, 2004.P. 279.

[4]. Dmitriev Yuri Albertovich. The form of the state and its constitutional and legal basis // Golovistikova Anastasia Nikolaevna, Dmitriev Yuri Albertovich. Problems of the theory of state and law: textbook. Moscow: Eksmo, 2005.S. 291, 295. 
[5]. Shagieva Rosalina Vasilievna. The form of the state // Theory of state and law: textbook / ed. Mikhail Mikhailovich Rassolov. M.: UNITY-DANA, Law and Law, 2008. P.101.

[6]. Abdulaev Magomed Imranovich. Theory of state and law: textbook. Moscow: Publishing house 2006. P.89.

[7]. Kozhevnikov Vladimir Valentinovich, Kozhenevsky Victor Boleslavovich, Rybakov Vladimir Alekseevich. Theory of state and law: textbook / otv. ed. V.V. Kozhevnikov. Moscow: Prospect, 2017, p. 100.

[8]. Vorotnikov Andrey Alekseevich, Khapaev Andrey Aleksandrovich. Leader state as the main type of authoritarianism: problem statement // Legal policy and legal life. 2011. No. 1.C. 29-32, 33.

[9]. Petrov Vladimir Sergeevich. Theoretical problems of the essence, content and form of the state: author. dis ... doctor. jurid. Sci., Leningrad: Leningrad State University, 1968, p. 28. [ten]. Kudryavtsev Yuri Anatolievich. Political regimes: classification and main types // Jurisprudence. 2002. No. 1. S.202.204.

[11]. Nazarenko Pavel Anatolyevich. Democracy and totalitarianism as types of political regimes and their historical perspective in Russia // Democracy and totalitarianism: problems of confrontation (political regimes in the modern world): Materials of interuniversity. scientific and practical. seminar St. Petersburg, November 15, 1999 / under the general ed. Victor Petrovich Salnikov. St. Petersburg: St. Petersburg University of the Ministry of Internal Affairs of Russia., 1999. Pp. 43-44.

[12]. Tirskikh Maxim Gennadievich. Law in states with an authoritarian political regime // Siberian legal bulletin. 2011.No. 3. Pp.109, 110.

[13]. Chirkin Veniamin Evgenievich. Constitutional law of foreign countries: textbook. Moscow: Yurist, 2007. Pp. 200-201, 202.

[14]. Political science on the Russian background: textbook / hand. Victor Vasilievich Ryabov. Moscow: Ray, 1993. P. 304.

[15]. Lukyanova Elena Anatolyevna, Shablinsky Ilya Georgievich. Authoritarianism and Democracy. Moscow: Thought, 2018.Pp. 18-19, 51, 75.

[16]. Rasskazov Leonid Pavlovich. Theory of state and law: textbook. Moscow: RIOR, 2008. P. 116.

[17]. Spiridonov Lev Ivanovich. Theory of state and law: textbook. Moscow: Prospect, 1995. Pp. 53-54.

[18]. Pyanov Nikolai Andreevich. Consulting on the theory of state and law: textbook. Irkutsk: Irkutsk state. University, 2010. Pp. 127-128.

[19]. Chirkin Veniamin Evgenievich. State science: textbook. Moscow: Yarest, 1999.Pp. 195, 196.

[20]. Golosov Grigory Vasilievich. Comparative Political Science: Textbook. Novosibirsk: Publishing house of Novosibirsk University, 1995. Pp. 51-62.

[21]. Protasov Valery Nikolaevich, Protasova Natalia Valerievna. Lectures on general theory of law and theory of the state. Moscow: Gorodets, 2010.Pp. 140, 141.

[22]. Kharitonova Oksana Gennadievna. Non-democratic political regimes // Political Science. 2012. No 3. P.24.

[23]. Lukyanov Vladimir Yurievich. Political science: textbook. Saint Petersburg: SPbGU ITMO, 2007. P. 6.

[24]. Roman Anatolyevich Romashov, Mikhail Viktorovich Salnikov. Authoritarian political regime: an attempt at an objective assessment // Democracy and totalitarianism: problems of confrontation (political regimes in the modern world). St. Petersburg: St. Petersburg University of the Ministry of Internal Affairs of Russia. 1999. P. 9.

[25]. Naumova Nina Fedorovna. Transition period: world experience and our problems // Communist. 1990.No.8. P.11. 
[26]. Sorokin Vitaly Viktorovich. Theory of state and law of the transition period: textbook. Barnaul: AltSU Publishing House, 2007, p. 54.

[27]. Korkunov Nikolai Mikhailovich. History of philosophy of law (textbook for lectures). SPb: Type. M. M. Stasyulevich, 1896. P. 45.

[28]. Fedorov Vasily Andreevich. The evolution of authoritarian regimes in the East. Oriental literature, 1992. P. 185.

[29]. Vorozheikina Tatiana Evgenievna. Authoritarian regimes of the twentieth century and modern Russia: similarities and differences // Bulletin of public opinion. 2009. No 4. P.55.

[30]. Ozhegov Sergey Ivanovich. Dictionary of the Russian language. Moscow, 1984. P. 698.

[31]. Philosophical Encyclopedic Dictionary / ed. Ivan Timofeevich Frivol. Moscow: The science, 2000. P. 458.

[32] Vengerov Anatoly Borisovich. Theory of state and law: textbook. Moscow: Omega-L, 2007. P. 157.

[33]. Sumbatyan Yuri Gaikovich. Totalitarianism as a category of political sociology // Sociological studies. 1994. No. 1. Pp.13, 14.

[34]. Rassokha Igor Nikolaevich. Theses on totalitarianism // Polis. 1995. No. 2 Pp. 147-148.

[35]. Perevalov Viktor Dmitrievich. Theory of state and law: textbook. Moscow: Yurayt, 2012. P. 311, 314.

[36]. Arend Hannah. The origins of totalitarianism / per. from English. Moscow: TsentrKom, 1996. P. 232.

[37]. Mazhirina Anna Alexandrovna. The ideology of a totalitarian society: the methodology of scientific analysis // History of state and law. 2013. No 1. Pp. 37,

[38]. Hayek Friedrich. The road to slavery / lane. from English. Moscow: New publishing house, 2005. Pp. 145, 147.

[39]. Ilyin Ivan Alexandrovich. From democracy to totalitarianism // Sobr. Op. in 10 volumes. Vol.2. Book. 1. Moscow: Russian book. 1993. P. 114.

[40]. Pozdnyakov Elgiz Abdulovich. Philosophy of Politics in 2 Volumes. Vol. 1. Moscow: Progress, 1994. P. 216.

[41]. Deleuze Gilles, Guattari Felix. Anti-Oedipus. Capitalism and schizophrenia. Yekaterinburg: U-Factoria, 2007.Pp. 53-54.

[42]. Zavyalov Yuri Stepanovich. Totalitarianism as a kind of political regime // State and Law. 2010.No.5. P.80.

[43]. Zatonsky Victor Alexandrovich. Democratic regime is the optimal form of functioning of a strong state // State power and local government. 2009. No. 7. Pp. 14-15.

[44]. Daria Ivanovna Degteva. Authoritarian and totalitarian political regimes // Bulletin of the Moscow State. open university. Series, 2012. No. 3. Pp. 74, 76.

[45]. Kaitukov Valery Mikhailovich. Evolution of diktat: Experiments in the psychophysiology of history. Moscow:MP, 1992. P. 55.

[46]. Law against the formation of new parties of July 4, 1933 / doc20vek.rusnode/1342 (date of access: 19.11 .19$)$.

[47]. The law on overcoming the plight of the people and the state of March 24, 1933 // cyberpedia.su (date of access: 19.11.19).

[48]. Marchenko Mikhail Nikolaevich. Sources of law: textbook. Moscow: Prospect, 2011.P. 221.

[49]. Manov Grigory Naumovich. Signs of the state: new reading / otv. ed. Nikolay Nikolaevich Deev. // Political problems of the theory of the state. Moscow: Izd-vo IGiP RAN, 1993. P. 43.

[50]. Rassokha Igor Nikolaevich. Theses on totalitarianism // Polis. 1995. No. 2. Pp. 149-150.

[51]. Butenko Anatoly Pavlovich. Sociological questions of the history and theory of totalitarianism // Sociological studies. 1998. No. 6. Pp. 31, 32. 
[52]. Kochesokov Robert Khazhismelovich. Totalitarianism: a philosophical and political study: dis ... doctor. philosopher. sciences. Rostov n / D, 1992. Pp. 12-13, 14.

[53]. Marchenko Mikhail Nikolaevich. Theory of State and Law: Textbook. Moscow: Zertsalo, 2011. P. 403. 